\title{
COMMENTARY
}

\section{The mesenchymal stromal cell magic bullet finds yet another target}

\author{
Claire Masterson ${ }^{1}$ and Daniel O'Toole ${ }^{2^{*}}$ \\ See related research by Rojas et al., http://stemcellres.com/content/5/2/42
}

\begin{abstract}
Rojas and colleagues have presented an exciting paper demonstrating yet another relevant preclinical setting in which the mesenchymal stromal cell has a potential therapeutic application. What is particularly interesting about this study is that it addresses a disease, blood-borne systemic sepsis, which has multiple complex host responses and involves a variety of disparate organs and immune cell types. Here, the authors focus on how this injury relates more specifically to the lung, with quite dramatic improvements in several assessed injury parameters. Where does this latest demonstration of mesenchymal stromal cell efficacy leave us with regard to getting these cell therapies to the acute respiratory distress syndrome patient?
\end{abstract}

The mesenchymal stromal cell (MSC) as a proposed treatment for acute respiratory distress syndrome (ARDS) appears to be rapidly approaching the moment of truth for any new drug. We have the disease, we have the medicine, and we have the preclinical data - now for the important part. Rojas and colleagues' paper informs us of another possible application of the MSC: treatment of ARDS as a consequence of a systemic infection [1].

Of note, especially in the acute clinical setting of ARDS, is the fact that this MSC is administered directly from cryopreservation. There has been much recent debate as to whether a wake-up period is essential for the beneficial effects seen with MSCs in injury models, and it is heartening to see that an off-the-shelf product such as MultiStem (Athersys, Cleveland, OH, USA) can be used in a rapid, multiorgan failure setting such as

\footnotetext{
* Correspondence: daniel.otoole@nuigalway.ie

${ }^{2}$ Department of Medicine, National University of Ireland Galway, University

Road, Galway, Ireland

Full list of author information is available at the end of the article
}

sepsis. This observation is of enormous importance because there are now up to 10 years of promising findings in models that have utilized freshly harvested passaging MSCs, with some trepidation as to whether a $-150^{\circ} \mathrm{C}$ freezer stock of MSCs in the intensive care department was ever likely to be the eventual outcome. While confirming some findings [2], this is also a direct contradiction of some earlier work that failed to demonstrate adequate therapeutic potential of MSCs immediately after thaw from cryostorage [3].

There are, however, still some concerns and possible missing pieces in this jigsaw leading to a picture of a perfected translation to the clinic. Firstly, this study utilizes bacteria-derived lipopolysaccharide as the injurious agent. Whilst this recapitulates many of the host inflammatory responses in a sepsis setting, it does not address the additional necessity of bacteria clearance from the host. While antibiotics may go some way towards alleviating this concern, an injury model utilizing clinically isolated pathogens with administration of a relevant broadspectrum antibiotic would raise confidence immensely in the MultiStem product's real-world efficacy. Indeed, recent work has begun to address the direct antibacterial effects of the MSC alongside its ability to enhance the function of macrophages and perhaps other leukocyte populations $[4,5]$. Furthermore, and while not a comment directed at this study of systemic sepsis, the persistence of Escherichia coli (or its products) as the preferred causative of pneumonia in lung injury research is perhaps occluding the reality of multiple, indeed often unidentified, pathogen involvement in the aetiology of pneumonia-induced ARDS.

Another caveat is that while in certain aspects it is appealing due to possible enhanced safety and a lower required dose of MSCs, intratracheal (or in this case the even more invasive intrabronchial) administration of any appreciable liquid volume of therapeutic may be a tall
C Biomed Central

(C) 2014 Masterson and O'Toole; licensee BioMed Central Ltd. The licensee has exclusive rights to distribute this article, in any medium, for 12 months following its publication. After this time, the article is available under the terms of the Creative Commons Attribution License (http://creativecommons.org/licenses/by/4.0), which permits unrestricted use, distribution, and reproduction in any medium, provided the original work is properly credited. The Creative Commons Public Domain Dedication waiver (http://creativecommons.org/publicdomain/zero/1.0/) applies to the data made available in this article, unless otherwise stated. 
order in an established ARDS patient due to the excess fluid infiltration into the lung air space. Adding more liquid to an already poorly performing lung may be a risk the physician is unwilling to take. Intratracheal/intrabronchial studies offer a wealth of information with regards to mechanism of action, but the success thus far of numerous studies using the intravenous route would appear to make this the most promising with respect to ultimate delivery to the patient.

Despite this, preclinical validation of any possible therapeutic for the devastating condition of sepsis/ARDS is to be welcomed, and we look forward intently to following up the MultiStem MSC as it forges it way towards success in the true clinical setting.

Abbreviations

ARDS: Acute respiratory distress syndrome; MSC: Mesenchymal stromal cell.

\section{Competing interests}

The authors declare that they have no competing interests.

\section{Authors' contributions}

The authors contributed equally to the preparation, writing and proofreading of this manuscript. Both authors read and approved the final manuscript.

\section{Acknowledgements}

The authors are supported by The Health Research Board Ireland, Science

Foundation Ireland and the European Research Council FP7 program.

\section{Author details}

'Department of Anaesthesia, National University of Ireland Galway, University Road, Galway, Ireland. ${ }^{2}$ Department of Medicine, National University of Ireland Galway, University Road, Galway, Ireland.

\section{Published: 04 Jul 2014}

\section{References}

1. Rojas M, Cárdenes N, Kocyildirim E, Tedrow JR, Romagnoli MR, Cáceres E, Dean R, Ting A, Bermúdez C: Human adult bone marrow-derived stem cells decrease severity of LPS-induced acute respiratory distress syndrome in sheep. Stem Cell Res Ther 2014, 5:42.

2. Haack-Sorensen M, Bindslev L, Mortensen S, Friiis T, Kastrup J: The influence of freezing and storage on the characteristics and functions of human mesenchymal stromal cells isolated for clinical use. Cytotherapy 2007, 9:328-337.

3. François M, Copland IB, Yuan S, Romieu-Mourez R, Waller EK, Galipeau J: Cryopreserved mesenchymal stromal cells display impaired immuno suppressive properties as a result of heat-shock response and impaired interferon- $\gamma$ licensing. Cytotherapy 2012, 14:147-152.

4. Krasnodembskaya A, Song Y, Fang X, Gupta N, Serikov V, Lee JW, Matthay MA: Antibacterial effect of human mesenchymal stem cells is mediated in part from secretion of the antimicrobial peptide LL-37. Stem Cells 2010, 28:2229-2238.

5. Mei SH, Haitsma JJ, Dos Santos CC, Deng Y, Lai PF, Slutsky AS, Liles WC, Stewart DJ: Mesenchymal stem cells reduce inflammation while enhancing bacterial clearance and improving survival in sepsis. Am J Respir Crit Care Med 2010, 182:1047-1057.

\section{$10.1186 /$ scrt471}

Cite this article as: Masterson and O'Toole: The mesenchymal stromal cell magic bullet finds yet another target. Stem Cell Research \& Therapy 2014, 5:82 